\title{
The normal short child
}

\section{Community study of children in Newcastle upon Tyne}

\author{
K. A. LACEY and J. M. PARKIN \\ From the Department of Child Health, University of Newcastle upon Tyne
}

\begin{abstract}
Lacey, K. A., and Parkin, J. M. (1974). Archives of Disease in Childhood, 49, 417. The normal short child: community study of children in Newcastle upon Tyne. This paper describes a community study of children who were born in 1960, 1961, and 1962, and who at the age of 10 years were of short stature but without evidence of organic disease. There was a tendency for the children to have low birthweights and delayed skeletal development, and most of their parents were short. In addition, the children scored poorly in tests of mental ability and attainment. Many of the children had been reared in poor social conditions and it is suggested that this played an important role in causing the short stature of at least one-third of the children.
\end{abstract}

In a community study of short children in Newcastle upon Tyne there was no evidence of organic disease causing the short stature in $82 \%$ of the children whose heights were under the 3rd centile and in $50 \%$ of children whose heights were more than 3 SD below the mean (Lacey and Parkin, 1974). It is of some importance to know whether these children are in fact normal or whether some influence other than organic disease is restraining their growth. This paper describes a study of these 'short normal' children.

\section{Method}

Selection. Two groups of children were studied. The first included all those children, born to mothers resident in Newcastle upon Tyne in 1960, who were less than the 3rd height centile at the age of 10 years and in whom there was no organic disease that could explain their stature. The second group comprised those apparently normal children born in 1961 and 1962 whose heights at 10 years were more than $3 \mathrm{SD}$ below the mean.

Data collected. The clinical and anthropometric information that was collected about these children has already been described (Lacey and Parkin, 1974). In addition, an attempt was made to quantify the environment in which they had been reared. Social class based upon the occupation of the father had been recorded at birth in the Newcastle Maternity Survey (Russell et al., 1963). Further information was collected from a number of sources. An attempt was made to discuss the

Received 19 November 1973. family of each child with the health visitor who was visiting or who had recently visited, and this was possible in 43 families. Additional information was obtained both from the child's infant welfare card and during home visits, when it was possible also to make a personal assessment of the state of the home and the care of the children. The information obtained allowed a detailed assessment of the home and the family circumstances of each child to be made, based on the following 5 items.

(1) Care of children. This was graded as good, average, or poor, taking into consideration the quality of food and clothing, the cleanliness of the child, and the general level of parental interest and supervision. No family was graded as poor unless this was the independent assessment of the health visitor.

(2) State of the home. A grading of good, average, or poor was based upon the adequacy of the accommodation and the degree of order and cleanliness in the home.

(3) Social agencies. Intervention by either the N.S.P.C.C. or the Social Services Department.

(4) Parental absence. Any period of parental absence due to separation, death, or imprisonment.

(5) Parental unemployment. A period of unemployment of the father was recorded if this exceeded 3 months before the child's 3rd birthday or 1 year thereafter.

In practice it was found that certain families had caused concern to health visitors and social agencies over a considerable period. A great deal of information about them was available from the infant welfare card, the 
health department, and the social services department, and this was readily confirmed at home visits.

For each child the social data were used to make a social score for the family, the details of which are given in Table I. Where doubt existed, families always were

TABLE I

Criteria for social scores

\begin{tabular}{|c|c|}
\hline Social score & Criteria \\
\hline 3 & $\begin{array}{l}\text { (a) Care of children 'Poor', } \\
\text { or (b) contact with social agencies, } \\
\text { or (c) imprisonment of father, } \\
\text { or (d) state of home 'Poor' and parental } \\
\text { separation or death } \\
\text { (a) State of home 'Poor', } \\
\text { or (b) parental separation or death. } \\
\text { or (c) significant period of unemployment } \\
\text { All others }\end{array}$ \\
\hline
\end{tabular}

given the better grading and as a result this study is likely to have underestimated the amount of social disruption.

Assessment of the items 'care of children' and 'state of home', graded as described above, had been made by health visitors for all children in the 1961 and 1962 cohorts of the Newcastle Survey of Child Development (N.S.C.D.) when they were 3 years of age (G. A. Neligan, personal communication, 1973). This prospectively collected information was available for only a minority of the children included in this study, but it did provide whole population control data for comparative purposes.

\section{Results}

A. Children below the 3rd centile (1960 cohort of the N.S.C.D.)

82 children were studied, 33 males and 49 females, the mean age of the group at the time of examination being $11 \cdot 4 \pm 0 \cdot 4$ years.

Causes of short stature. The height of a normal child is determined by three factors: genetic

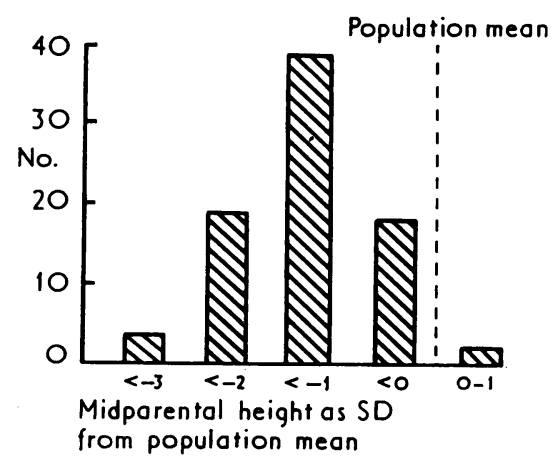

FIG. 1.-Distribution of midparental heights. potential, which is related to midparental height (Tanner, Goldstein, and Whitehouse, 1970); tempo of development, of which bone age is a measure (Tanner, 1962); and quality of intrauterine growth, as measured by birthweight for gestational age (Ounsted and Taylor, 1971). The importance of each of these influences was examined in the whole group.

The distribution of the midparental heights shown in Fig. 1 is normal but shifted markedly to the left when compared with the population mean (Tanner et al., 1970), indicating that the majority of the parents of the children were short.

The distribution of skeletal ages of the children shown in Fig. 2 is significantly lower $(t=6 \cdot 6, P$ $<0.001$ ) than the published standards (Tanner,

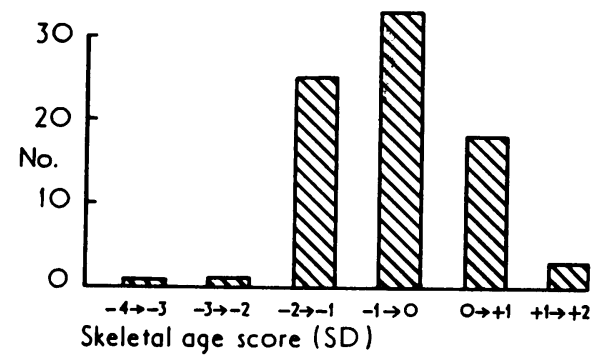

FIG. 2.-Distribution of skeletal ages as SD scores. $1 S D=1$ year.

Whitehouse, and Healy, 1962). In 28 children the skeletal age was delayed by more than 1 year. This delay in skeletal maturation was accompanied by a similar delay in the appearance of secondary sexual characteristics in girls. A cumulative frequency distribution curve indicated that the age at which $50 \%$ of the girls had early breast development was 11.9 years, the mean age for attainment of this stage of development in a normal population being $11 \cdot 1$ years (Marshall and Tanner, 1969). Only 3 boys had pubic hair development, but no conclusions can be drawn from this as signs of puberty appear later in boys than in girls (Marshall and Tanner, 1970).

The distribution of birthweight centiles using local standards (G. A. Neligan, personal communication, 1973) is shown in Fig. 3. There is an excess of children of low birthweight, 10 children having weights below the 5 th centile and a further 7 between the 5 th and 10 th centiles. When allowance was made for maternal height (Tanner and Thomson, 1970), the birthweights of 7 children remained below the 5 th centile.

A multiple regression analysis (Table II) showed that these 3 factors each contributed independently 
TABLE II

Multiple regression analysis. Relation between child's height and independent variables

\begin{tabular}{|c|c|c|c|c|c|}
\hline Independent variable & $\begin{array}{c}\text { Correlation } \\
\text { coefficient }\end{array}$ & Significance & $\begin{array}{c}\text { Regression } \\
\text { coefficient }\end{array}$ & F ratio & Significance \\
\hline
\end{tabular}

Note: Dependent variable is height of child as SD score.

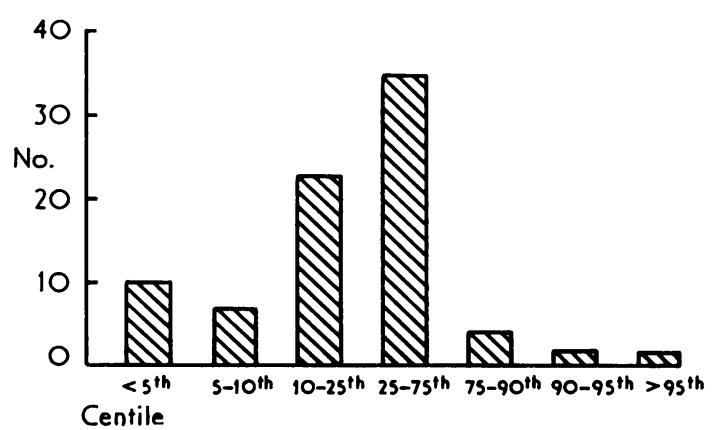

FIG. 3.-Distribution of birthweight for gestational age centiles.

to the variation in heights in the group of children. Though there was some overlap in their roles in individuals, we classified the children into four groups based on the following definitions:

(a) Familial. Children whose heights were within 2 SD of the mean when allowance was made for their parents's heights, using the midparental height chart devised by Tanner et al. (1970). Though these charts are standardized only for children under the age of 9 years, we felt justified in using them in this study as only a minority of the children had entered puberty.

(b) Slow development. Children whose bone ages were delayed by more than 6 months and whose heights fell above the 3 rd centile on the midparental height chart when allowance was made for their delayed development by plotting height for skeletal age rather than for chronological age. Though many of the parents of the children in this group were short, midparental height alone was not sufficient to account for the children's stature.

(c) Small-for-dates. Children whose birthweights for gestational age were below the 5th centile and in whom no other explanation for their shortness was evident.

(d) Uncertain. Children who did not fulfil any of the above criteria.

The number of children falling into each category is shown in Table III.

\section{TABLE III}

Social scores of children in different diagnostic groups

\begin{tabular}{l|r|r|r|r}
\hline \multirow{1}{*}{ Diagnosis } & No. & \multicolumn{3}{|c}{ Social score } \\
\cline { 2 - 4 } & & 1 & 2 & 3 \\
\hline Familial & 55 & 26 & 14 & 15 \\
Slow development & 15 & 8 & 2 & 5 \\
Small-for-dates & 4 & 1 & 1 & 2 \\
Uncertain & 8 & 4 & 1 & 3 \\
\hline Total & 82 & 39 & 18 & 25 \\
\hline
\end{tabular}

Social factors. Low midparental height, delayed bone age, or a low birthweight for gestational age may be the indicators of a genetic reason for short stature in a normal child, but also may be found in children stunted as a result of an adverse environment. Thus, parents who have been reared in conditions of deprivation and thereby become stunted adults may rear their own children in a similar way. These children might appear to be short for genetic reasons when they are really stunted as a result of the abnormal environment. Similarly, delay in skeletal maturation or limited intrauterine growth may be normal phenomena or the result of adverse environment. It seemed important, therefore, to examine carefully the environment in which these short normal children had been reared.

(a) Social class. The social class distribution of the children is shown in Fig. 4, together with the social class distribution recorded at birth of all the 


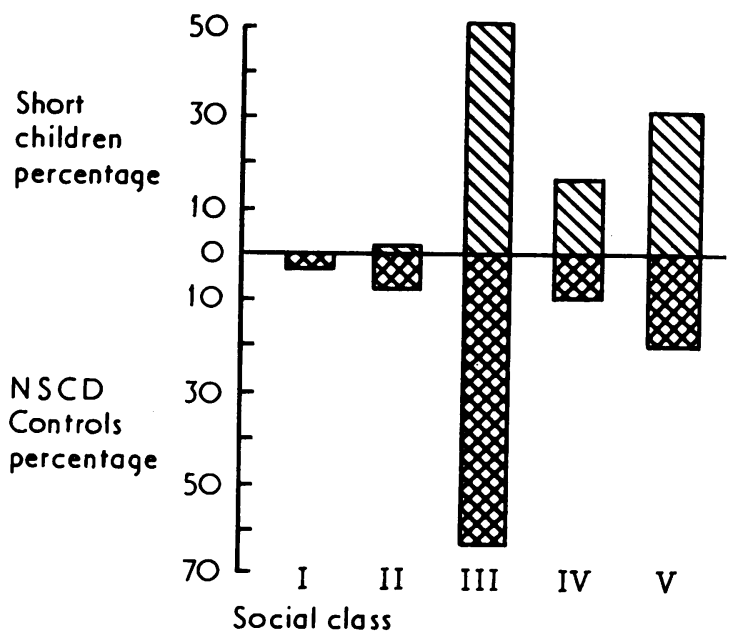

FIG. 4.-Social class distribution at birth of normal short children and of children from the 1960 cohort of the Newcastle Survey of Child Development (N.S.C.D.) remaining in Newcastle at 10 years of age.

children in the 1960 cohort who were still living in the city at the age of 10 years. It is clear that the distributions are significantly different $(P<0.01)$, the population of short children containing an excess from social class $V$ families and none from social class $\mathrm{I}$.

(b) Size of family. Fig. 5 shows the percentage of families in which there were 4 or more children under the age of 21, comparing this with similar data from the National Child Development Survey (Davie, Butler, and Goldstein, 1972). In each social class there is a tendency for the short children to belong to large families, and this is significant in social classes III and V. Altogether 55 of the 82 children came from families in which there were more than 4 children.

(c) Care of children. More specific evaluation of the circumstances in which the children had been reared was made by considering the 'care of children' gradings. In Table IV the distribution of this grading for the short children is compared with the similar assessment made by health visitors for social class V children in the 1961 cohort of the N.S.C.D. Children from social class $V$ were used as controls in order to eliminate the effect of the social class distribution of the short children. It is clear that there is a significant excess of families with the worst grading for care of children in the study population.

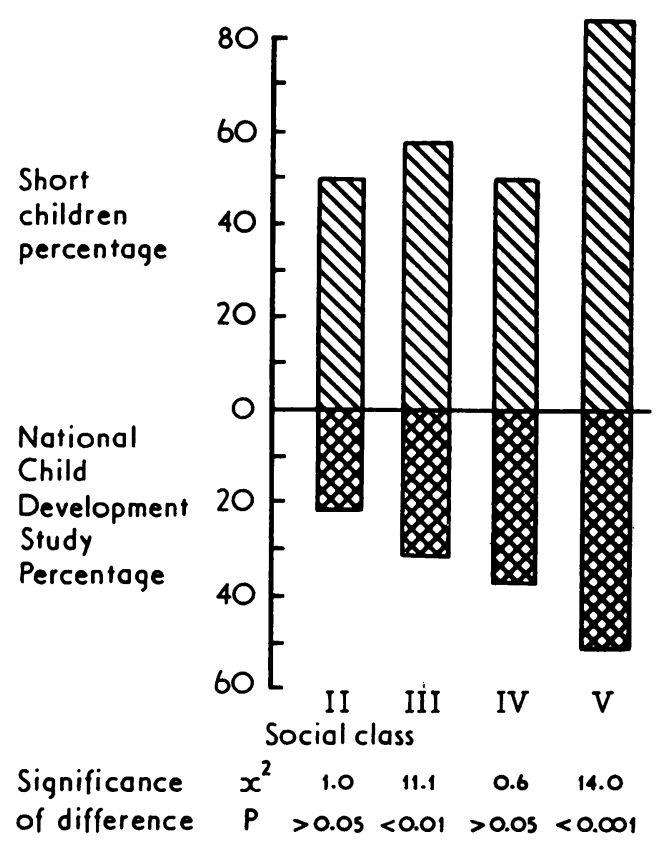

FIG. 5.-Percentage of families with 4 or more children under the age of 21 years.

TABLE IV

Distribution of gradings of 'care of children'

\begin{tabular}{l|c|c|c}
\hline \multirow{2}{*}{ Group } & \multicolumn{2}{|c|}{ Percentage of total } & Total no. \\
\cline { 2 - 3 } & $\begin{array}{l}\text { Good or } \\
\text { average }\end{array}$ & Poor & \\
\hline Short children & 70 & 30 & 82 \\
$\begin{array}{l}\text { N.S.C.D. } \\
\text { social class V }\end{array}$ & 90 & 10 & 495 \\
\hline
\end{tabular}

N.S.C.D., Newcastle Survey of Child Development.

(d) Social score. In Table $\mathrm{V}$ the number of children in each social score category is shown together with the distribution of the various adverse factors contributing to the score. $30 \%$ of the children came from inadequate families and $22 \%$ from families which were classified as doubtful. It can be seen from Table III that children with the worst social score were found in each diagnostic group.

Intellectual development. Clearly a significant proportion of short normal children come from unsatisfactory homes. It therefore seemed important to examine their intellectual development and school performance. In Tables VI and VII the 
TABLE V

Distribution of adverse social factors in each social score group

\begin{tabular}{l|c|c|c|c}
\hline & \multicolumn{2}{|c|}{ Social Score (\%) } & \multicolumn{1}{|c|}{$\begin{array}{c}\text { Incidence in } \\
\text { whole group (\%) }\end{array}$} \\
\cline { 2 - 3 } & 1 & 2 & $3 \cdot$ & \\
\hline $\begin{array}{l}\text { Father unemployed } \\
\text { now }\end{array}$ & 5 & 68 & 59 & 31 \\
$\begin{array}{l}\text { Father unemployed } \\
\text { Child aged 0-3 yr }\end{array}$ & 0 & 38 & 68 & 29 \\
$\begin{array}{l}\text { Father unemployed } \\
\text { Child aged 3-10 yr }\end{array}$ & 0 & 83 & 68 & 39 \\
$\begin{array}{l}\text { Parents separated } \\
\text { Social agency } \\
\text { contacts }\end{array}$ & 0 & 16 & 56 & 20 \\
\hline Mean family size & $4 \cdot 3$ & $6 \cdot 6$ & $5 \cdot 8$ & 15 \\
No. in each group & 39 & 18 & 25 & $5 \cdot 0$ \\
\hline
\end{tabular}

mean of the National Foundation for Educational Research verbal and nonverbal and the sentence reading test scores are shown for the short children who attended normal schools compared with controls from the total normal school population of the 1960 cohort of the N.S.C.D. It is clear that the scores of the short children from each social class are lower than those of the controls. This is largely the result of the very low scores of children from poor homes (social score 3), since the scores of children from adequate homes (social score 1) do not differ significantly from the controls. In addition, $6(7 \%)$ short children attended schools for the educationally subnormal, the comparable figure for the control population being $2 \%$. It therefore appears that many of the children were stunted educationally as well as developmentally.

Anthropometry related to social score. As the tests of intellectual development seemed to be affected by home conditions, we examined the results of the physical measurements of the children in relation to their social scores. The results are shown in Table VIII.

There is a tendency for the children from poor homes to be shorter, to have less subcutaneous fat, to have greater delay in skeletal maturation, and to have grown more slowly than the children from adequate homes. Nevertheless, neither the mean skinfold thickness measurements nor the weight for height centile distribution (Scott, 1961) of the children from poor backgrounds differed from published population standards.

\section{B. Very short children}

There were 12 children from the 1961 and 1962 cohorts of the N.S.C.D. whose heights were more than 3 SD below the mean and in whom there was no organic disease causing their short stature. The details of these children and the 4 very short normal children from the 1960 cohort are given in Table IX. It is clear that in the majority of very short children there are a number of influences restraining their growth, only 2 children having simple familial short stature. In addition, there was a strong tendency for the children to score poorly in intelligence tests and 7 of them were attending schools for the educationally subnormal.

There were 2 children who failed to achieve adequate growth hormone levels after exercise stimulation, and in both the cause of this was considered to be severe deprivation. Case 8 was taken into care because of parental neglect, and shortly after her admission to a children's home her serum growth hormone level after exercise was $1 \mu \mathrm{IU} / \mathrm{ml}$. She was retested 1 month later when the peak serum growth hormone after Bovril

TABLE VI

Mean of verbal and nonverbal scores by social class and social score

\begin{tabular}{|c|c|c|c|c|c|c|c|c|}
\hline \multirow[t]{2}{*}{$\begin{array}{l}\text { Social } \\
\text { class }\end{array}$} & \multirow[t]{2}{*}{$\begin{array}{l}\text { Scores of } \\
\text { N.S.C.D. } \\
\text { control children }\end{array}$} & \multirow[t]{2}{*}{$\begin{array}{l}\text { Scores of all } \\
\text { short children }\end{array}$} & \multicolumn{2}{|c|}{$\begin{array}{l}\text { Significance of } \\
\text { difference between } \\
\text { score of N.S.C.D. } \\
\text { and short children }\end{array}$} & \multirow[t]{2}{*}{$\begin{array}{l}\text { Scores of short } \\
\text { children with } \\
\text { social score } 1\end{array}$} & \multicolumn{2}{|c|}{$\begin{array}{l}\text { Significance of } \\
\text { difference between } \\
\text { score of N.S.C.D. } \\
\text { and short children } \\
\text { with social score } 1\end{array}$} & \multirow[t]{2}{*}{$\begin{array}{l}\text { Scores of short } \\
\text { children with } \\
\text { social score } 3\end{array}$} \\
\hline & & & $t$ & $\mathbf{P}$ & & $\mathbf{t}$ & $\mathbf{P}$ & \\
\hline II & $\begin{array}{c}102 \cdot 5 \pm 13 \cdot 7 \\
(202)\end{array}$ & $\begin{array}{c}113 \cdot 5 \pm 7 \cdot 9 \\
(2)\end{array}$ & $1 \cdot 1$ & NS & $\begin{array}{c}113 \cdot 5 \pm 7 \cdot 9 \\
(2)\end{array}$ & $1 \cdot 13$ & NS & - \\
\hline III & $\begin{array}{c}(202) \\
95 \cdot 6 \pm 13 \cdot 1 \\
(1716)\end{array}$ & $\begin{array}{c}89 \cdot 8 \pm 12 \cdot 4 \\
(40)\end{array}$ & $2 \cdot 8$ & $<0.1$ & $\begin{array}{l}94 \cdot 4 \pm 11 \cdot 5 \\
(24)\end{array}$ & 0.4 & NS & $\begin{array}{c}80 \cdot 5 \pm 9 \cdot 8 \\
(8)\end{array}$ \\
\hline IV & $\begin{array}{c}94 \cdot 0 \pm 13 \cdot 7 \\
(214)\end{array}$ & $\begin{array}{c}90 \cdot 5 \pm 14 \cdot 4 \\
(13)\end{array}$ & 0.9 & NS & $\begin{array}{c}91 \cdot 9 \pm 17 \cdot 1 \\
(7)\end{array}$ & 0.4 & NS & $\begin{array}{c}83 \cdot 0 \pm 8 \cdot 4 \\
(3)\end{array}$ \\
\hline V & $\begin{array}{c}89 \cdot 4 \pm 12 \cdot 1 \\
(403)\end{array}$ & $\begin{array}{c}81 \cdot 5 \pm 9 \cdot 4 \\
(21)\end{array}$ & $2 \cdot 9$ & $<0.1$ & $\begin{array}{c}87 \cdot 6 \pm 12 \cdot 1 \\
(4)\end{array}$ & 0.3 & NS & $\begin{array}{c}78 \cdot 8 \pm 8 \cdot 4 \\
\quad(11)\end{array}$ \\
\hline
\end{tabular}

Note: Number of children in each category is in parentheses. N.S.C.D., Newcastle Survey of Child Development; NS, not significant. 
TABLE VII

Mean of reading test scores by social class and social score

\begin{tabular}{|c|c|c|c|c|c|c|c|c|}
\hline \multirow[t]{2}{*}{$\begin{array}{l}\text { Social } \\
\text { class }\end{array}$} & \multirow[t]{2}{*}{$\begin{array}{l}\text { Scores of } \\
\text { N.S.C.D. } \\
\text { control children }\end{array}$} & \multirow[t]{2}{*}{$\begin{array}{l}\text { Sccres of all } \\
\text { short children }\end{array}$} & \multicolumn{2}{|c|}{$\begin{array}{l}\text { Significance of } \\
\text { difference between } \\
\text { score of N.S.C.D. } \\
\text { and short children }\end{array}$} & \multirow[t]{2}{*}{$\begin{array}{l}\text { Scores of short } \\
\text { children with } \\
\text { social score } 1\end{array}$} & \multicolumn{2}{|c|}{$\begin{array}{l}\text { Significance of } \\
\text { difference between } \\
\text { score of N.S.C.D. } \\
\text { and short children } \\
\text { with social score } 1\end{array}$} & \multirow[t]{2}{*}{$\begin{array}{l}\text { Scores of short } \\
\text { children with } \\
\text { social score } 3\end{array}$} \\
\hline & & & $t$ & $\mathbf{P}$ & & $t$ & $\mathbf{P}$ & \\
\hline II & $\begin{array}{c}105 \cdot 6 \pm 14 \cdot 9 \\
(200)\end{array}$ & $\begin{array}{c}122 \cdot 0 \pm 8 \cdot 4 \\
(2)\end{array}$ & $1 \cdot 5$ & NS & $\begin{array}{c}122 \cdot 0 \pm 8 \cdot 4 \\
(2)\end{array}$ & $1 \cdot 5$ & NS & - \\
\hline III & $\begin{array}{c}98 \cdot 0 \pm 14 \cdot 1 \\
(1751)\end{array}$ & $\begin{array}{c}92 \cdot 3+17 \cdot 0 \\
(40)\end{array}$ & $2 \cdot 9$ & $<0 \cdot 1$ & $\begin{array}{c}98 \cdot 0 \pm 16 \cdot 6 \\
(24)\end{array}$ & $0 \cdot 0$ & NS & $\begin{array}{c}81 \cdot 8+12 \cdot 1 \\
(8)\end{array}$ \\
\hline IV & $\begin{array}{c}95 \cdot 9 \pm 14 \cdot 6 \\
(208)\end{array}$ & $\begin{array}{c}91 \cdot 5 \pm 13 \cdot 4 \\
(13)\end{array}$ & $1 \cdot 0$ & NS & $\begin{array}{c}95 \cdot 3 \pm 16 \cdot 1 \\
(7)\end{array}$ & $0 \cdot 1$ & NS & $85 \cdot 3 \pm 7 \cdot 4$ \\
\hline V & $\begin{array}{c}90 \cdot 5 \pm 14 \cdot 0 \\
(395)\end{array}$ & $\begin{array}{c}79 \cdot 8 \pm 11 \cdot 5 \\
(20)\end{array}$ & $3 \cdot 3$ & $<0.1$ & $\begin{array}{c}89 \cdot 5 \div 16 \cdot 8 \\
(4)\end{array}$ & $0 \cdot 1$ & NS & $\begin{array}{c}75 \cdot 5 \pm 7 \cdot 6 \\
(10)\end{array}$ \\
\hline
\end{tabular}

Note: Number of children in each category is in parentheses.

stimulation was $20 \mu \mathrm{IU} / \mathrm{ml}$. The postexercise serum growth hormone level for the second child (Case 5) was $5 \cdot 2 \mu \mathrm{IU} / \mathrm{ml}$. A younger sib had been taken into care previously because of severe physical neglect and abuse and there was considerable evidence from the records of the Social Services Department that the standards of care provided by the mother had been grossly inadequate.

\section{Discussion}

The findings of this survey indicate that short stature in children is associated with a number of social and biological characteristics. The parents of the children are short and they tend to come from the lower social classes, to have large families, and to rear their children in poor social conditions. There is a tendency for the children themselves to be of low birthweight and to have slow physical growth as measured by skeletal development. In addition, they score poorly in tests of mental ability and attainment.

Although assessment of the social circumstances of the children based on the health visitors's assessments was subjective, it was supported by objective evidence relating to the economic circumstances of the families. In 55 families the father had experienced at least one period of unemployment, the families tended to be large, and many fathers belonged to the most poorly paid sections of the community. There is evidence (Berry and

TABLE VIII

Some measurements related to social score

\begin{tabular}{|c|c|c|c|c|c|}
\hline \multirow[t]{2}{*}{ Measurement } & \multirow[t]{2}{*}{ Study population } & \multirow[t]{2}{*}{$\begin{array}{l}\text { Social score } 1 \\
\text { children }\end{array}$} & \multirow[t]{2}{*}{$\begin{array}{l}\text { Social score } 3 \\
\text { children }\end{array}$} & \multicolumn{2}{|c|}{$\begin{array}{c}\text { Significance of difference } \\
\text { between measurements of } \\
\text { children with social scores } \\
1 \text { and } 3\end{array}$} \\
\hline & & & & $t$ & $\mathbf{P}$ \\
\hline Age $(y r)$ & $\begin{array}{l}11 \cdot 4 \pm 0 \cdot 4 \\
(82)\end{array}$ & $\begin{array}{l}11 \cdot 3 \pm 0 \cdot 4 \\
(39)\end{array}$ & $\begin{array}{l}11 \cdot 4 \pm 0 \cdot 4 \\
(25)\end{array}$ & 0.5 & NS \\
\hline Height at above age (SD score) & $\begin{array}{c}2 \cdot 2 \pm 0 \cdot 4 \\
(82)\end{array}$ & $\begin{array}{c}2 \cdot 1 \pm 0 \cdot 4 \\
(39)\end{array}$ & $\begin{array}{c}-2 \cdot 3 \pm 0 \cdot 5 \\
(25)\end{array}$ & $1 \cdot 9$ & $<0.05$ \\
\hline $\begin{array}{l}\text { Skinfold thickness (mean of subscapular } \\
\text { and triceps) (SD score) }\end{array}$ & $\begin{array}{l}+0 \cdot 3 \pm 0.8 \\
(81)\end{array}$ & $\begin{array}{c}+0.4 \pm 0.9 \\
(39)\end{array}$ & $\begin{array}{c}+0.03 \pm 0.8 \\
(24)\end{array}$ & $1 \cdot 7$ & $<0.05$ \\
\hline Upper arm circumference $(\mathrm{cm})$ & $\begin{array}{l}19 \cdot 5 \pm 1 \cdot 4 \\
\quad(78)\end{array}$ & $\begin{array}{c}19 \cdot 3 \pm 1 \cdot 2 \\
(39)\end{array}$ & $\begin{array}{c}19 \cdot 0 \pm 1 \cdot 2 \\
(23)\end{array}$ & 0.9 & NS \\
\hline $\begin{array}{l}\text { Height velocity between ages } 5 \text { and } 10 \\
(\mathrm{~cm} / \mathrm{yr})\end{array}$ & $\begin{array}{l}4 \cdot 9 \pm 0 \cdot 7 \\
(80)\end{array}$ & $\begin{array}{l}5 \cdot 0 \pm 0 \cdot 8 \\
(39)\end{array}$ & $\begin{array}{l}4 \cdot 7 \pm 0 \cdot 5 \\
(24)\end{array}$ & $1 \cdot 7$ & 0.05 \\
\hline Skull circumference (SD score) & $\begin{array}{c}-1 \cdot 1 \pm 1 \cdot 0 \\
(80)\end{array}$ & $\begin{array}{l}-1 \cdot 0 \pm 0 \cdot 8 \\
(39)\end{array}$ & $\begin{array}{c}-1 \cdot 4 \pm 1 \cdot 2 \\
(24)\end{array}$ & $1 \cdot 5$ & NS \\
\hline Skeletal age (SD score) & $\begin{array}{c}-0 \cdot 6 \pm 0 \cdot 8 \\
(81)\end{array}$ & $\begin{array}{c}-0.5 \pm 0.8 \\
(39)\end{array}$ & $\begin{array}{c}-0.9 \pm 0.8 \\
(24)\end{array}$ & $1 \cdot 9$ & $<0.05$ \\
\hline
\end{tabular}

Note: Number of children in each category is in parentheses. 
TABLE IX

Some characteristics of 16 very short normal children

\begin{tabular}{|c|c|c|c|c|c|c|c|c|c|}
\hline $\begin{array}{l}\text { Year of } \\
\text { birth }\end{array}$ & $\begin{array}{c}\text { Case } \\
\text { no. }\end{array}$ & Sex & $\begin{array}{c}\text { Height } \\
\text { (SD score) }\end{array}$ & $\begin{array}{l}\text { Skeletal age } \\
\text { (SD score) }\end{array}$ & $\begin{array}{l}\text { Birthweight for } \\
\text { gestational age } \\
\text { (centile) }\end{array}$ & $\begin{array}{c}\text { Mean } \\
\text { verbal- } \\
\text { nonverbal } \\
\text { score }\end{array}$ & $\begin{array}{l}\text { Social } \\
\text { score }\end{array}$ & $\begin{array}{l}\text { Midparental } \\
\text { height (SD } \\
\text { score) }\end{array}$ & $\begin{array}{l}\text { Cause of short } \\
\text { stature }\end{array}$ \\
\hline 1962 & $\begin{array}{r}1 \\
2 \\
3 \\
4 \\
5 \\
6 \\
7 \\
8 \\
9 \\
10 \\
11 \\
12 \\
13 \\
14 \\
15 \\
16\end{array}$ & $\begin{array}{c}F \\
F \\
M \\
M \\
M \\
M \\
M \\
F \\
M \\
F \\
M \\
F \\
M \\
F \\
M \\
F\end{array}$ & $\begin{array}{l}-3 \cdot 4 \\
-3 \cdot 6 \\
-3 \cdot 1 \\
-3 \cdot 1 \\
-3 \cdot 8 \\
-3 \cdot 0 \\
-3 \cdot 4 \\
-3 \cdot 4 \\
-3 \cdot 8 \\
-3 \cdot 2 \\
-3 \cdot 3 \\
-3 \cdot 0 \\
-3 \cdot 2 \\
-3 \cdot 1 \\
-4 \cdot 3 \\
-3 \cdot 2\end{array}$ & $\begin{array}{r}-0.8 \\
-1 \cdot 6 \\
-0.2 \\
-0.3 \\
-1 \cdot 4 \\
+0.2 \\
-0.6 \\
0.0 \\
-5 \cdot 3 \\
-0.7 \\
+0 \cdot 1 \\
-1 \cdot 3 \\
-1.9 \\
-1 \cdot 3 \\
-0.5\end{array}$ & $\begin{array}{c}10-25 \text { th } \\
<5 \text { th } \\
<5 \text { th } \\
<5 \text { th } \\
25-75 \text { th } \\
5-10 \text { th } \\
<5 \text { th } \\
<5 \text { th } \\
25-75 \text { th } \\
25-75 \text { th } \\
25-75 \text { th } \\
25-75 \text { th } \\
<5 \text { th } \\
25-75 \text { th } \\
<5 \text { th } \\
25-75 \text { th }\end{array}$ & $\begin{array}{c}64 \\
76 \\
88 \\
82 \\
71 \\
102 \\
79 \\
59 \\
96 \\
74 \\
88 \\
87 \\
\text { ESN } \\
95 \\
\text { ESN } \\
94\end{array}$ & $\begin{array}{l}1 \\
3 \\
3 \\
2 \\
3 \\
1 \\
1 \\
2 \\
3 \\
2 \\
1 \\
1 \\
1 \\
3 \\
3 \\
2 \\
2\end{array}$ & $\begin{array}{l}-2 \cdot 2 \\
-3 \cdot 8 \\
-2 \cdot 1 \\
-2 \cdot 8 \\
-\overline{-1} \cdot 2 \\
-1 \cdot 8 \\
-3 \cdot 2 \\
-2 \cdot 7 \\
-3 \cdot 3 \\
-1 \cdot 9 \\
-1 \cdot 0 \\
-1 \cdot 7 \\
-0 \cdot 3 \\
-4 \cdot 1 \\
-2 \cdot 1\end{array}$ & $\begin{array}{l}\text { Multiple } \\
\text { Multiple } \\
\text { Multiple } \\
\text { Familial } \\
\text { Severe deprivation } \\
\text { Uncertain } \\
\text { Small-for-dates } \\
\text { Multiple } \\
\text { Slow development } \\
\text { Familial } \\
\text { Uncertain } \\
\text { Slow development } \\
\text { Multiple } \\
\text { Slow development } \\
\text { Multiple } \\
\text { Multiple }\end{array}$ \\
\hline
\end{tabular}

ESN, school for the educationally subnormal.

Hollingsworth, 1963; Lambert, 1964) that increasing family size is associated with a progressive decrease in the quality of diet, and that food, clothing, and bedding often are inadequate in the families of chronically unemployed, unskilled fathers (Ministry of Social Security, 1967). The incidence of social disruption was even higher in the group of children whose care was graded poor by health visitors, and it therefore seems inevitable that children in this group particularly had suffered a severe degree of physical deprivation.

What was the relative contribution of the environmental and genetic factors in causing the short stature of these children? The findings that short children have delayed bone ages and are born to short parents were not unexpected since height and bone age are hereditable traits (Carter, 1962; Tanner, 1962), and it could be argued that these children were short entirely as a result of their genetic endowment. However, this hypothesis does not explain why their average measured intelligence was low. Though intelligence also is an inherited characteristic, there is good evidence that it may be adversely affected by unfavourable social and cultural factors (Haywood, 1967). The fact that the intelligence test scores of the short children in this study were clearly related to social score strongly suggests that at least in the $30 \%$ of children from poor homes environmental factors had played an important part in retarding their intellectual development.

Adverse environment also is known to delay physical and skeletal development. The growth of children is slow during war-time famine (Acheson,
1960), and poor maternal care (Douglas and Blomfield, 1958) and disordered social environment (Miller et al., 1960) are associated with impaired growth. Severe malnutrition is known to retard skeletal development (Jones and Dean, 1959; Greulich, Crismon, and Turner, 1953), and in this country boys from social classes IV and V tend to be delayed in skeletal maturation when compared with those from social classes I and II (Acheson and Hewitt, 1954). It is also well established that children from large families tend to be shorter than those from small ones (Goldstein, 1971), and this effect of family size is likely to be environmental, since it was not present in a group of upper middleclass families (Douglas, 1969).

The 2 is good evidence, then, that disordered social environment can impair both physical and intellectual development. Many of the children in this study had been reared in very poor circumstances and this seemed to account for their low measured intelligence and attainment. It seems probable that in addition the physical and skeletal development of these particular children had been impaired by their unfavourable environment. The mechanism for this is not clear. Suppression of growth hormone release was only shown in 2 children, perhaps those most deprived, and it seems likely that the ways in which poor environment can impair growth are complex. Nevertheless, though some of the children in the study undoubtedly had inherited short stature and in many others it is not possible to estimate precisely the relative roles of genetic and environmental factors, our evidence suggests that poor home conditions have been of 
importance in causing the short stature of at least $30 \%$ of the children under the $3 \mathrm{rd}$ height centile in Newcastle upon Tyne. Short stature, therefore, should be regarded as a disease of the social environment (Miller et al., 1960) and as an important pointer to a group of socially deprived children.

We thank Dr. G. A. Neligan for allowing us to use data from the N.S.C.D.; Mr. J. S. Clowes and Mr. J. R. Reed of the University Computing Laboratory for help with data analysis; Professor R. Hall in whose laboratory the $\mathrm{TSH}$ and growth hormone estimations were done; and Professors S. D. M. Court and J. M. Tanner for advice.

K.A.L. was supported by a grant from the Scientific and Research Committee of the Royal Victoria Infirmary, Newcastle upon Tyne.

\section{REFERENCES}

Acheson, R. M. (1960). Effects of nutrition and disease on human growth. In Human Growth, p. 73. Ed. by J. M. Tanner. Pergamon Press, Oxford.

Acheson, R. M., and Hewitt, D. (1954). Stature and skeletal maturation in the pre-school child. British fournal of Preventive and Social Medicine, 8, 59.

Berry, W. T. C., and Hollingsworth, D. F. (1963). The indices of nutritional change in Britain. Proceedings of the Nutrition Society, 22, 48.

Carter, C. O. (1962). Human Heredity, p. 95. Penguin Books, Harmondsworth, Middlesex.

Davie, R., Butler, N., and Goldstein, H. (1972). From Birth to Seven. Second Report of the National Child Development Study, p. 31. Longmans, London.

Douglas, J. W. B. (1969). Effects of early environment on later development. Fournal of the Royal College of Physicians, 3, 359.

Douglas, J. W. B., and Blomfield, J. M. (1958). Children Under Five, p. 60. Allen and Unwin, London.

Goldstein, H. (1971). Factors influencing the height of 7 year old children. Human Biology, 43, 92.

Greulich, W. W., Crismon, C. S., and Turner, M. L. (1953). The physical growth and development of children who survived the atomic bombing of Hiroshima or Nagasaki. Fournal of Pediatrics, 43, 121.

Haywood, C. (1967). Environmental factors in intellectual development: the concept of dynamic intelligence. In Psychopathology of Mental Development, p. 69. Ed. by J. Zubin and G. A. Jervis. Grune and Stratton, New York and London.

Jones, P. R. M., and Dean, R. F. A. (1959). The effects of kwashiorkor on the development of the bones of the knee. fournal of Pediatrics, 54, 176.

Lacey, K. A., and Parkin, J. M. (1974). The causes of short stature: a community study of children in Newcastle upon Tyne. Lancet, 1, 42.

Lambert, R. (1964). Nutrition in Britain-1950-1960. Occasional Papers on Social Administration, No. 6, p. 17. Codicote Press, Welwyn.

Marshall, W. A., and Tanner, J. M. (1969). Variations in pattern of pubertal changes in girls. Archives of Disease in Childhood, 44, 291.

Marshall, W. A., and Tanner, J. M. (1970). Variations in the pattern of pubertal changes in boys. Archives of Disease in Childhood, 45, 13.

Miller, F. J. W., Court, S. D. M., Walton, W. S., and Knox, E. G. (1960). Growing Up in Newcastle upon Tyne, p. 147. Oxford University Press, London.

Ministry of Social Security (1967). Administration of the Wage Stop. H.M.S.O., London.

Ounsted, M., and Taylor, M. E. (1971). The postnatal growth of children who were small-for-dates or large-for-dates at birth. Developmental Medicine and Child Neurology, 13, 421.

Russell, J. K., Fairweather, D. V. I., Millar, D. G., Brown, A. M., Pearson, R. C. M., Neligan, G. A., and Anderson, G. S. (1963). Maternity in Newcastle upon Tyne-a community study. Lancet, 1, 711 .

Scott, J. A. (1961). Report on the Heights and Weights (and Other Measurements) of School Pupils in the County of London in 1959. London County Council, London.

Tanner, J. M. (1962). Growth at Adolescence, 2nd ed., pp. 56, 113. Blackwell, Oxford.

Tanner, J. M., Goldstein, H., and Whitehouse, R. H. (1970). Standards for children's height at ages 2-9 years allowing for height of parents. Archives of Disease in Childhood, 45, 755 .

Tanner, J. M., and Thomson, A. M. (1970). Standards for birthweight at gestation periods from 32 to 42 weeks, allowing for maternal height and weight. Archives of Disease in Childhood, 45, 566 .

Tanner, J. M., Whitehouse, R. H., and Healy, M. J. R. (1962). $A$ New System for Estimating Skeletal Maturity from the Hand and Wrist, with Standards Derived from a Study of 2600 Healthy British Children. Centre International de l'Enfance, Paris.

Correspondence to Dr. J. M. Parkin, Children's Department, Royal Victoria Infirmary, Queen Victoria Road, Newcastle upon Tyne NE1 4LP. 